\title{
A Granular Cell Tumor of the Rectum: A Case Report and Review of the Literature
}

\author{
Seung Yoon Yang, Byung Soh Min, Woo Ram Kim ${ }^{1}$ \\ Department of Surgery, Yonsei University College of Medicine, Seoul; ${ }^{1}$ Department of Surgery, CHA Bundang Medical Center, CHA \\ University, Seongnam, Korea
}

A granular cell tumor (GCT) is an uncommon mesenchymal lesion that rarely occurs in the colon and the rectum. We describe the case of 51-year-old man with a 2-cm-sized rectal GCT $10 \mathrm{~cm}$ above the anal verge that was incidentally detected after a screening colonoscopy. Preoperative radiologic studies demonstrated a suspicious submucosal rectal mass with mesorectal fat infiltration, but without circumferential resection margin threatening, extramural vessel invasion, and regional lymph-node enlargement. The tumor was resected by using a transanal endoscopic operation (TEO) without immediate postoperative complications. The final pathology revealed that the tumor consisted of a GCT that had invaded the subserosa with clear margins. It had no other risk factors for malignancy according to Fanburg-Smith criteria. We systematically reviewed the English literature by using PubMed and Google Scholar. This report may be the first documented case in the literature to describe a TEO for a GCT that had invaded the subserosa in the rectum.

\section{Keywords: Granular cell tumor; Colon and rectum; Gastrointestinal tract}

\section{INTRODUCTION}

A granular cell tumor (GCT) is an uncommon mesenchymal cell tumor, which was first described as a myogenic tumor by Abrikossoff, a Russian pathologist, in 1926 [1]. It commonly occurs in the head and the neck, including the oral cavity, skin and soft tissue, but is rarely found in the gastrointestinal tract (GIT). Although it may be found anywhere in the GIT, the esophagus is the most common site, followed by the duodenum, anus and stomach, but its occurrence in the colon and rectum is very rare [2-6]. We systematically reviewed the English literature by using PubMed and Google Scholar to look for an appropriate treatment for a patient with a GCT that had been found incidentally and revealed invasion of the subserosal rectal wall. This report may be

Received: March 28, 2017 - Accepted: October 2, 2017

Correspondence to: Woo Ram Kim, M.D.

Department of Surgery, CHA Bundang Medical Center, CHA University, 59 Yatap-ro, Bundang-gu, Seongnam 13496, Korea

Tel: +82-31-780-1874, Fax: +82-31-780-5886

E-mail: christtome81@chamc.co.kr

(C) 2017 The Korean Society of Coloproctology

This is an open-access article distributed under the terms of the Creative Commons Attribution NonCommercial License (http://creativecommons.org/licenses/by-nc/4.0) which permits unrestricted noncommercial use, distribution, and reproduction in any medium, provided the original work is properly cited. the first documented case in the literature to describe a transanal endoscopic operation (TEO) for treatment of a patient with a GCT in the rectum that had invaded the subserosa.

\section{CASE REPORT}

A 51-year-old Korean man with a past medical history of hypertension and hyperlipidemia was referred on Jan 7, 2014, to the Yonsei University Health System for treatment of a known GCT. The colonoscopic finding was an approximately $2.0-\mathrm{cm}$-sized, hard, rectal mass $10 \mathrm{~cm}$ above the anal verge (Fig. 1A). Histopathology findings indicated a GCT composed of round tumor cells having abundant granular cytoplasm with no evidence of malignancy. The patient had no other symptoms when he visited a local hospital on December 13, 2013, for a screening colonoscopy. He had no specific family history, but his sister had had breast cancer. He had a 10 pack/yr history of smoking and a body mass index of $25.7 \mathrm{~kg} / \mathrm{m}^{2}$.

On admission, the patient appeared well. The laboratory findings were all within normal limits. Although the computed tomography (CT) findings made us suspicious of T3 rectal cancer (Fig. 1B), subsequent magnetic resonance imaging (demonstrated a probable submucosal rectal mass with mesorectal fat infiltration above $8 \mathrm{~cm}$ from anal verge $(\mathrm{Rb})$, but without circumferential re- 


\section{Coloproctology
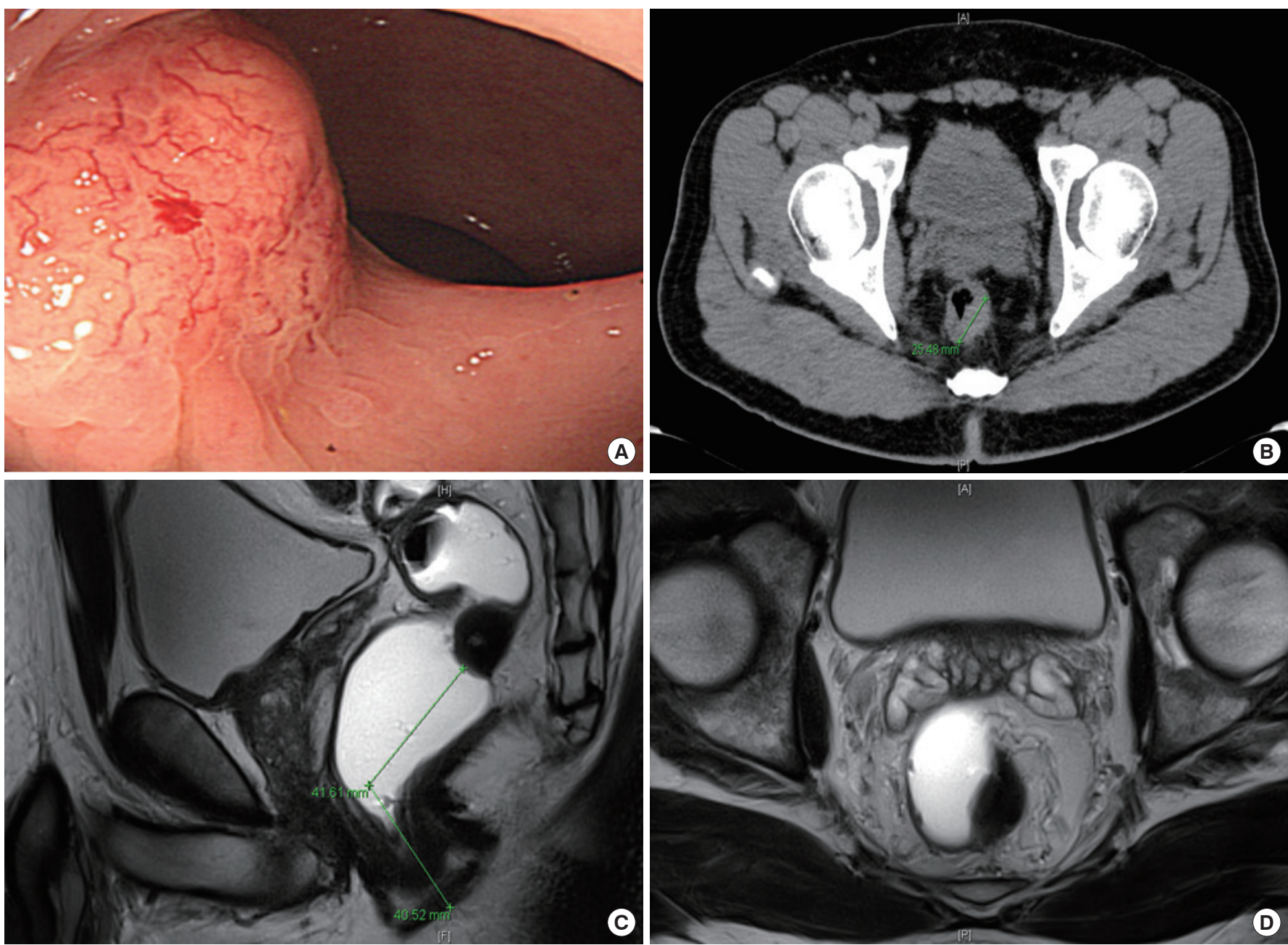

Fig. 1. (A) Colonoscopy detected an approximately 2-cm-sized, yellowish, submucosal tumor in the rectum. It was hard in consistency. (B) Computed tomography revealed a suspicion of rectal cancer with T3. (C, D) Magnetic resonance imaging demonstrated a probable submucosal rectal mass with mesorectal fat infiltration above $8 \mathrm{~cm}$ from the anal verge $(\mathrm{Rb})$, but without circumferential resection margin threatening, extramural vessel invasion, and regional lymph-node enlargement.

section margin threatening, extramural vessel invasion, or regional lymph-node enlargement (Fig. 1C). His chest $\mathrm{x}$-ray showed neither active lung disease nor evidence of lung metastasis.

When we reviewed the English literature, we were able to find only a few cases involving a GCT that had extended to the level of the muscularis propria. Our colorectal team, including colorectal surgeons, oncologists, gastroenterologists, and pathologists, discussed an appropriate treatment for this rare case. Even though we first considered a low anterior resection and lymph-node dissection, we finally decided to perform a TEO, with which we had had plentiful experience for patients with early rectal cancer. The surgery was performed on January 14, 2014. The patient had an uneventful postoperative course and was discharged 6 days after surgery. Two weeks later, the patient visited our clinic, and the final pathology revealed that the tumor consisted of a $1.7 \times 1.5-\mathrm{cm}$

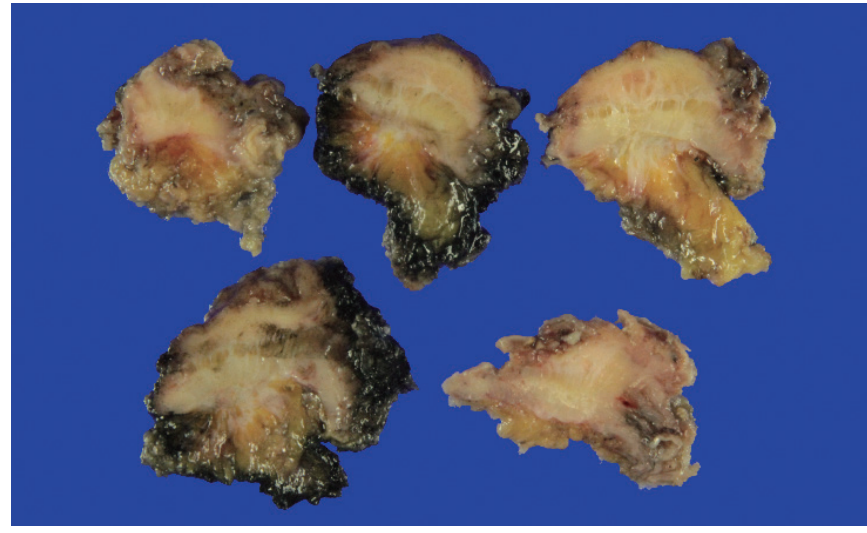

Fig. 2. Gross specimen of the $1.7 \times 1.5-\mathrm{cm}$ granular cell tumor in the rectum. 

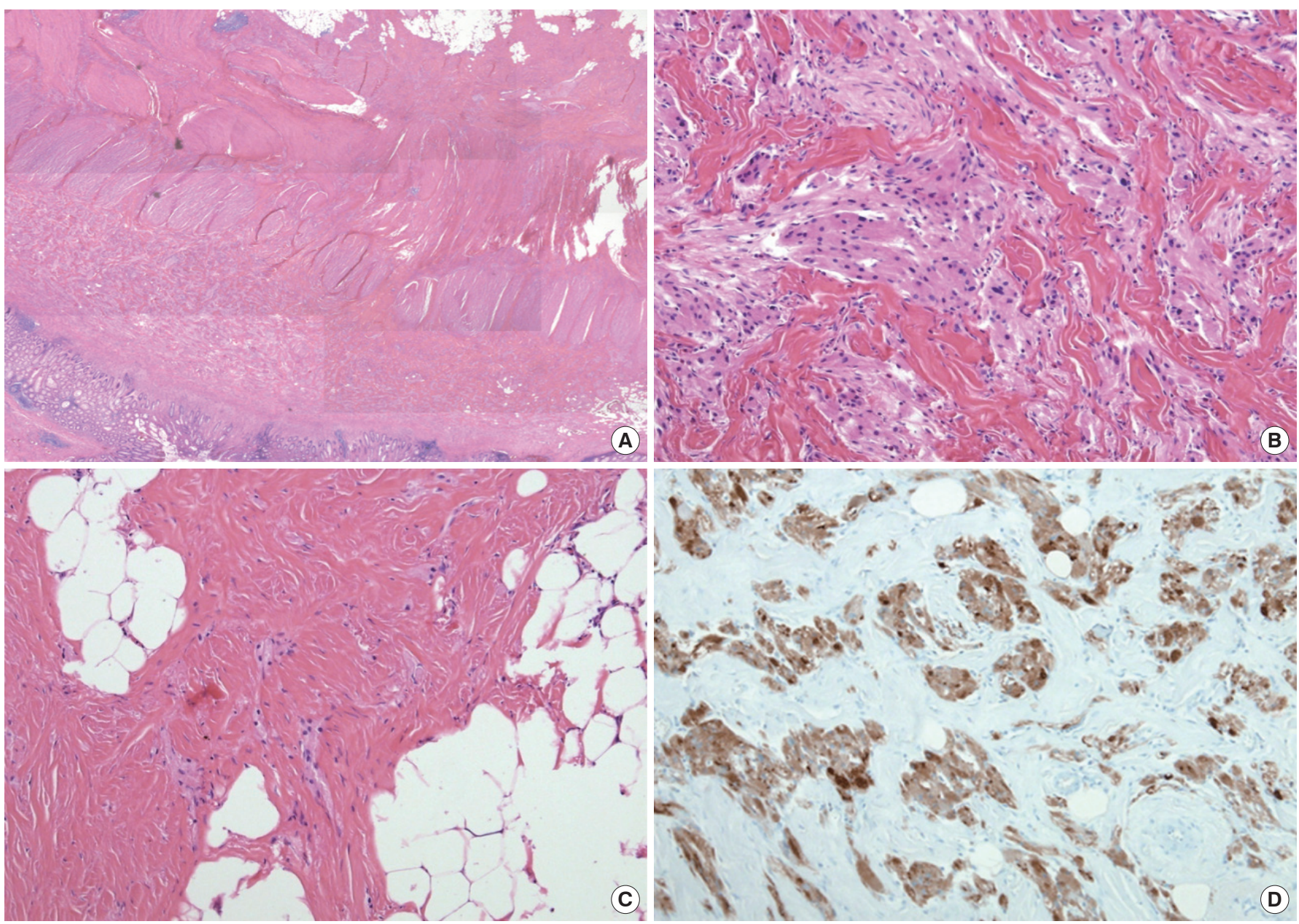

Fig. 3. A submucosal tumor revealed by histological examination in resected tissue. (A) Resected lesion showing a submucosal tumor covered with normal mucosa and with subserosa invasion (H\&E, $\times 40)$. (B) Higher magnification view of the tumor, which revealed nonuniform large tumor cells with slightly pleomorphic nuclei (H\&E, $\times 200)$. (C) Higher magnification view of a tumor composed of large tumor cells with abundant granular cytoplasm and small round nuclei (H\&E, $\times 200)$. (D) Diffuse, strong expression of S-100 protein in the tumor shown by immunohistochemistry $(\times 200)$.

GCT (Fig. 2), which had been positively stained for the S-100 protein (Fig. 3D) and had invaded the subserosa with clear margins (Fig. 3A-C). The patient exhibited no other risk factors for malignancy according to Fanburg-Smith criteria [7]. Because of the rarity of this disease entity and the lack of experience with a GCT with subserosal invasion, short-term follow-up was recommended. The CT scan and sigmoidoscopy performed nine months later showed no evidence of recurrence.

\section{DISCUSSION}

A colorectal GCT is a very rare submucosal tumor that usually follows a benign course. It is incidentally described during a screening endoscopy. In most cases, a polypectomy or an endoscopic mucosal resection (EMR) is usually sufficient to deal with this rare disease entity [8-10]. Although a malignant GCT is extremely uncommon, such cases have been reported in the literature as representing $1 \%-2 \%$ of all GCTs $[7,11,12]$. However, its recurrent pattern and prognosis are not fully understood. In 1998, Fanburg-Smith et al. [7] suggested 6 diagnostic criteria for malignant GCTs. Six histologic criteria were assessed: necrosis, spindling, vesicular nuclei with large nucleoli, increased mitotic activity ( $>2$ mitoses/10 high-power fields at $\times 200$ magnification), high nuclear-to-cytoplasmic ratio, and pleomorphism. Those authors defined a GCT as a histological malignancy when three or more of these criteria were met. They also reported prognostic factors for patients with a GCT: local recurrence, metastasis, larger tumor size, older patient age, histologic classification as malignant, presence of necrosis, increased mitotic activity, spindling of tumor cells, vesicular nuclei with large nucleoli, and Ki-67 values less 
than $10 \%$ [7].

A colorectal GCT usually occurs within the submucosa with an intact mucosa surface, and extensions below the level of the muscularis propria are seldom reported in patients with a colorectal GCT. Cha et al. [8] reported in 2009 that GCTs were usually less than $2 \mathrm{~cm}$ in size and did not invade the muscularis propria. Although no guidelines for colorectal GCTs existed at that present, those author, according to the results of their retrospective case analysis, insisted that a benign lesion less than $2 \mathrm{~cm}$ in diameter and separated from the muscularis propria could be removed by using a EMR. On the other hand, Znati et al. [13] suggested that patients with a colonic GCT should be managed conservatively, with a polypectomy or an EMR for tumors less than $4 \mathrm{~cm}$ in size and with a segmental resection for tumors with larger sizes.

Recurrence is very rare after a curative resection of a GCT, but it does occur, although seldom. In 2010, Singhi and Montgomery [14] reported the occurrence of regrowth at the prior biopsy site owing to incomplete excision. However, the recurrence pattern of GCTs is still not known, so appropriate surgical margins have yet to be clarified for patients with a colorectal GCT.

We treated our patient by using a TEO with a clear resection margin, and the final pathology revealed that the tumor had invaded the subserosa. However, because the size of the GCT was less than $2 \mathrm{~cm}$ and the GCT was not suitable for malignancy according to Fanburg-Smith criteria [7], in our opinion, our procedure should be sufficient in this case, even though the patient will require close follow-up.

\section{CONFLICT OF INTEREST}

No potential conflict of interest relevant to this article was reported.

\section{REFERENCES}

1. Abrikossoff AL. Über Myome, ausgehend von der quergestreiften willkürlichen Muskulatur. Virchows Arch A Pathol Anat Histopathol 1926;260:215-33.

2. Melo CR, Melo IS, Schmitt FC, Fagundes R, Amendola D. Multicentric granular cell tumor of the colon: report of a patient with
52 tumors. Am J Gastroenterol 1993;88:1785-7.

3. Yamaguchi K, Maeda S, Kitamura K. Granular cell tumor of the stomach coincident with two early gastric carcinomas. Am J Gastroenterol 1989;84:656-9.

4. Lack EE, Worsham GF, Callihan MD, Crawford BE, Klappenbach S, Rowden G, et al. Granular cell tumor: a clinicopathologic study of 110 patients. J Surg Oncol 1980;13:301-16.

5. Nakachi A, Miyazato H, Oshiro T, Shimoji H, Shiraishi M, Muto Y. Granular cell tumor of the rectum: a case report and review of the literature. J Gastroenterol 2000;35:631-4.

6. Sohn DK, Choi HS, Chang YS, Huh JM, Kim DH, Kim DY, et al. Granular cell tumor of colon: report of a case and review of literature. World J Gastroenterol 2004;10:2452-4.

7. Fanburg-Smith JC, Meis-Kindblom JM, Fante R, Kindblom LG. Malignant granular cell tumor of soft tissue: diagnostic criteria and clinicopathologic correlation. Am J Surg Pathol 1998;22:77994.

8. Cha JM, Lee JI, Joo KR, Choe JW, Jung SW, Shin HP, et al. Granular cell tumor of the descending colon treated by endoscopic mucosal resection: a case report and review of the literature. J Korean Med Sci 2009;24:337-41.

9. Endo S, Hirasaki S, Doi T, Endo H, Nishina T, Moriwaki T, et al. Granular cell tumor occurring in the sigmoid colon treated by endoscopic mucosal resection using a transparent cap (EMR-C). J Gastroenterol 2003;38:385-9.

10. Yasuda I, Tomita E, Nagura K, Nishigaki Y, Yamada O, Kachi H. Endoscopic removal of granular cell tumors. Gastrointest Endosc 1995;41:163-7.

11. Matsumoto H, Kojima Y, Inoue T, Takegawa S, Tsuda H, Kobayashi A, et al. A malignant granular cell tumor of the stomach: report of a case. Surg Today 1996;26:119-22.

12. Uzoaru I, Firfer B, Ray V, Hubbard-Shepard M, Rhee H. Malignant granular cell tumor. Arch Pathol Lab Med 1992;116:206-8.

13. Znati K, Harmouch T, Benlemlih A, Elfatemi H, Chbani L, Amarti A. Solitary granular cell tumor of cecum: a case report. ISRN Gastroenterol 2011;2011:943804.

14. Singhi AD, Montgomery EA. Colorectal granular cell tumor: a clinicopathologic study of 26 cases. Am J Surg Pathol 2010;34: 1186-92. 